DIW BERLIN

Discussion

Papers

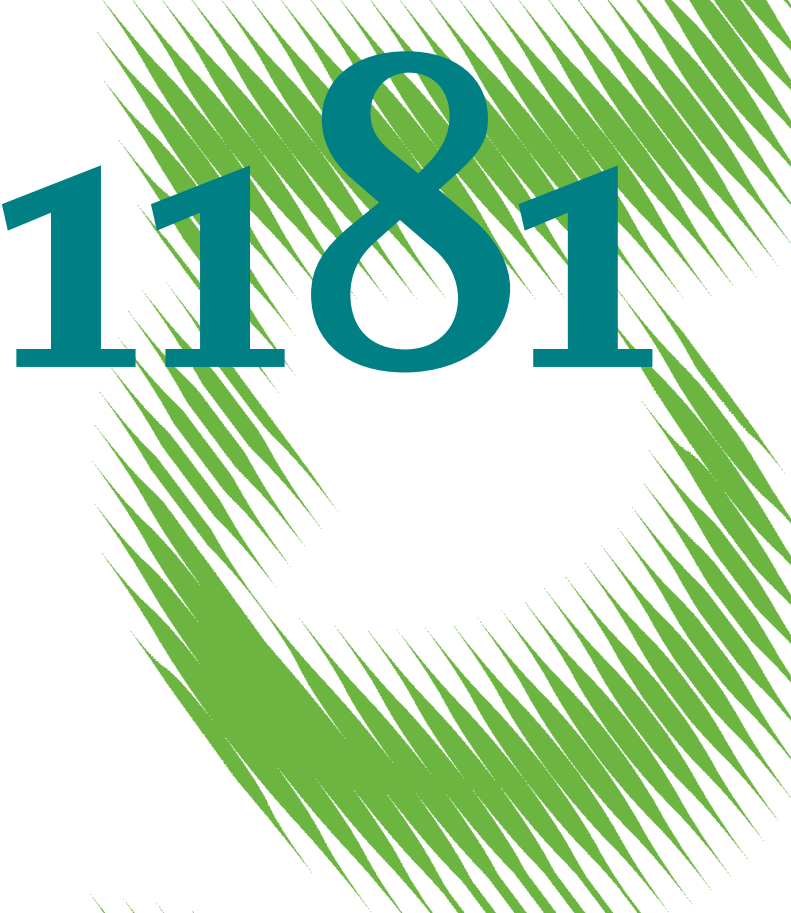

How Do Taxes Affect

Investment When Firms Face Financial Constraints? 
Opinions expressed in this paper are those of the author(s) and do not necessarily reflect views of the institute.

IMPRESSUM

(C) DIW Berlin, 2012

DIW Berlin

German Institute for Economic Research

Mohrenstr. 58

10117 Berlin

Tel. $+49(30) 89789-0$

Fax +49 (30) $89789-200$

http://www.diw.de

ISSN print edition $1433-0210$

ISSN electronic edition 1619-4535

Papers can be downloaded free of charge from the DIW Berlin website:

http://www.diw.de/discussionpapers

Discussion Papers of DIW Berlin are indexed in RePEc and SSRN:

http://ideas.repec.org/s/diw/diwwpp.html

http://www.ssrn.com/link/DIW-Berlin-German-Inst-Econ-Res.html 


\title{
How do taxes affect investment when firms face financial constraints? *
}

\author{
Martin Simmler ${ }^{\dagger}$ \\ January 5,2012
}

\begin{abstract}
This study uses a switching regression framework with known sample separation to analyze the effects of corporate income taxation on investment in case of binding and nonbinding financial constraints. By employing two different sample splitting criteria, payout behavior and the ratio of liabilities to total assets, I show that the elasticity of capital to its user costs in an auto-distributed-lag model is underestimated in case of neglecting the presence of financial constraints. For unconstrained firms, the elasticity of capital to its user costs is around -1 . For financially constrained firms the elasticity is statistically not different from zero. For the latter group instead, the results prevail by using the effective average tax rate to measure liquidity outflow through taxation that corporate taxation affects investment through changing internal finance.
\end{abstract}

Keywords: investment cash flow sensitivity; financial constraints; taxation; effective average tax rate, effective marginal tax rate, switching regression.

JEL Classification: H25, H32, G31

*I thank Nadja Dwenger for allowing me to use her routine for calculating firm-specific user costs of capital and Frank Fossen for methodological support as well as Viktor Steiner and the seminar participants at the DIW Berlin for valuable comments. The usual disclaimer applies.

${ }^{\dagger}$ German Institute for Economic Research (DIW Berlin), Mohrenstraße 58, 10117 Berlin, Germany, e-mail: msimmler@diw.de 


\section{Introduction}

If the world functioned as assumed by Modigliani and Miller (1958) in their famous theorem, firms' finance and investment decisions would be independent of each other and the discussion of financial constraints would be purely theoretical. Under these conditions, corporate income taxation affects investment only through changing the marginal costs of investment. However, a large body of literature suggests that capital markets are not perfect because of asymmetric information and transaction costs. While these reasons for incomplete capital markets and their effects on investment spending are analyzed in various ways, the potentially different effect of taxation on investment in case of binding financial constraints is neglected even as it is named in one of the first papers on financial constraints as an important aspect (Fazzari, Hubbard and Petersen (1988)). Closing this gap is the aim of this study.

Building upon the hierarchy of finance setting, this study questions whether corporate income taxation affects financially constrained and unconstrained firms differently. Theory on corporate taxation and financial constraints suggests this, arguing that for unconstrained firms only the effective marginal tax rate $(E M T R)$ matters for the evaluation of investment projects, whereas for constrained firms the effective average tax rate $(E A T R)$ is decisive since tax payments affect firm liquidity. In order to test this hypothesis, I use the neoclassical investment approach, where the EMTR is included in the investment equation through the user cost of capital and the EATR is explicitly included as one determinant of cash flow. The analysis is based on individual annual financial statements of German incorporated firms for the years 1991 to 2008. The empirical results of this study are in line with theory; the coefficient of the user costs of capital for unconstrained firms is around -1, whereas for constrained firms it is statistically not different from zero. For the $E A T R$, the reverse is true.

Methodologically, this study applies a switching regression approach with known sample separation. In addition to the often used dividend payout behavior as sample splitting criteria, the analysis employs a second sample splitting criterion, the debt ratio of the firm. Estimation is done via a two-stage standard Heckman-type technique; the selection equation is estimated using maximum likelihood and the structural equation using an instrumental variable approach to deal with measurement error, attenuation, and simultaneity bias. By using the switching regression framework, I address a criticism of prior studies, which analyzed financial constraints by splitting the sample according to a criterion that reflects the different degrees of firms' financial constraints, estimating both samples separately and comparing the estimated cash flow coefficients ${ }^{1}$. Although this approach dominated the financial constraints literature between

\footnotetext{
${ }^{1}$ An survey of the existing empirical studies is given by Schiantarelli (1995) and Hubbard (1998).
} 
1988 and $1998^{2}$, it is suggested that the used splitting criteria are likely to be endogenous, which would cause a potentially significant bias in the estimated coefficients. To overcome this shortcoming a switching regression framework can be used as within this setting the selfselection process is accounted for. Furthermore, Chatelain (2003) points out that this method provides additional intuition on the discriminatory power of the sample selection criteria.

Two other critique of previous studies are also considered. Both concern the interpretation of differences in the estimated cash flow coefficients for constrained and unconstrained firms. Firstly, Hubbard (1998) and Bond, Elston, Mairesse and Mulkay (2003b) suggest that cash flow would also be significant and potentially different for two groups, if cash flow were a proxy for the omitted variable future profitability in case of reduced form models or as a consequence of model misspecification for structural models. This issue is tackled by analyzing the effect of the user costs of capital, incorporating the EMTR, and the EATR, which is less likely to be correlated with future profitability. The second point is contributed by Kaplan and Zingales (1997, 2000), who present a theoretical and empirical counterexample in which firms classified as less financially constrained (facing a lower cost premium for the use of external finance) show greater cash flow sensitivity. They claim that the cash flow sensitivity is not linear but inversely $\mathrm{u}$-shaped. These considerations are based on the presence of two types of constrained firms, internal and external constrained firms, as shown by Cleary, Povel and Raith (2007). External constrained firms show positive and internal constrained firms negative cash flow sensitivity ${ }^{3}$. As shown by Hovakimian (2009), internal constrained firms have almost the same characteristics as external constrained firms but, although they are even smaller and younger, they can obtain sufficient finance (debt and new equity) due to their good investment possibilities. Although the data consists mostly of large companies, I classify firms that issue/issued new shares in the present or last period as financially unconstrained. ${ }^{4}$

The remainder of this article is organized as follows: The next section motivates the chosen investment model and summarizes the theoretical relationship between investment, taxation, and financial constraints. The dataset and the used variables are presented in section 3 . Afterwards, in section $4 \mathrm{I}$ describe the methodology, followed with the results in section 5 . Section

\footnotetext{
${ }^{2}$ Identical to this, but additionally restricting the other coefficients to be the same for both groups, is the approach that includes an interaction term in order to analyze whether firms with a specific characteristic respond differently to a change in cash-flow (see for example Guariglia (2007)).

${ }^{3}$ The inversely $\mathrm{u}$-shaped relationship can be explained by two oppositional effects, the cost and the revenue effects. For external constrained firms, the cost effect dominates. This effect captures the relationship that higher investment leads to higher borrowing, which increases the risk of liquidation and therefore raises the marginal cost of debt finance. For internal constrained firms, the revenue effect instead dominates, which represents the channel that increasing investment raises expected revenue which improves firms' ability to repay debt and thus reduces the marginal cost of debt finance.

${ }^{4}$ This is comparable to the method used by van Binsbergen, Graham and Yang (2010). They also define firms with equity issuance as financially unconstrained firms.
} 
6 concludes.

\section{Theory and Literature}

\subsection{Corporate Investment Models}

An important component for analyzing the effect of financial constraints on investment is the underlying investment model. In principle, three different investment models are commonly used in the literature, the neoclassical, the $q$-based, and the Euler-based approach 5 From these three, $q$-based ${ }^{6}$ models appear more frequently in the literature (i.e. Whited (1992), Hubbard, Kashyap and Whited (1995), Gilchrist and Himmelberg (1995), Audretsch and Elston (2002), Behr and Bellgardt (2000), Behr (2005)). As the Euler-based approach this approach is based on a dynamic optimization problem through considering adjustment costs. However, both models differ with respect to the modeling of the forecast process. In Euler-based models, the forecast process must be estimated, whereas $q$-based models try to use financial market information $]^{7}$ Although $q$-based models have the advantage that they are simple to implement they also have two shortcomings. First, in $q$-based analysis only publicly traded companies are included, since the market value of the firm is necessary for the construction of $q$, which is only available for publicly traded companies 8 . Second, analyzing capital market imperfection by using average $q$ as a proxy for marginal $q$ seems to be counterintuitive, since the equivalence of average and marginal $q$ only holds if finance and investment decisions are independent of each other, as shown by Hayashi (1982) Thus, Euler-based models seems to be preferable. However, it is pointed out that this approach does not identify financial constraints if a firm is constrained the same today as tomorrow (Gilchrist and Himmelberg (1995)). Studies relying on this approach include Bond and Meghir (1994a), Gilchrist (1991), Hubbard et al. (1995) and Bond et al. (2003b).

Compared to these two models, the neoclassical approach, introduced by Jorgenson (1963) and Eisner and Nadiri (1968), is based on a static optimization problem. Studies that use

\footnotetext{
${ }^{5}$ For a survey to these models, see Chirinko $(1993)$.

${ }^{6}$ The $q$-theory of investment is introduced by Keynes (1936), Brainard and Tobin (1968) and Tobin (1969) and is extended to models of investment assuming convex adjustment costs by Hayashi (1982).

${ }^{7}$ In $q$-based models the benefits over the life cycle for a capital good is expressed as the ratio of the market value of an additional unit of capital to its replacements costs. As shown by Hayashi (1982) under the assumption of competitive product and factor markets, linear homogenous production and adjustment cost technologies, homogenous capital and independence of investment and real and financial decision marginal $q$ equals average $q$, whereas average $q$ can be proxied by the market value of the firm divided by its replacement costs of capital.

${ }^{8}$ One way to use $q$-based models without accepting the data selection is the approach used by Behr (2005). He measures $q$ by using a vector autoregressive model to forecast future profitability.

${ }^{9}$ This argument is also suggested by Hubbard (1998) and Schiantarelli (1995).
} 
this approach include, for example, Chirinko and von Kalckreuth (2003) and Dwenger (2009). Although this approach has the weakness of ad-hoc dynamification for econometric purposes it allows to include non-publicly traded firms and ensures the identification of financial constraints if a firm is constrained as today as tomorrow. Since the focus of the paper is to analyze financial constraints the inclusion of unquoted firms - for which debt is an important source of finance - is crucial. In addition, it is also important to identify the effect of financial constraints when the degree of financial constraints a firms faces does not vary between years. Thus, I base my study on the neoclassical approach.

\subsection{Theory of Financial Constraints and Corporate Taxation}

According to the hierarchy of finance theory (Myers (1984)), a financially constrained firm can be thought of as a firm whose investment spending rises if its retained earnings increase. The use of retained earnings as a basic source of finance comes from the fact that retained earnings are assumed to be the firm's least expensive source of finance, followed by debt and then new shares. Thus, the theory states that a firm uses first retained earnings, then debt and at last new shares to finance its investment. Following this classification, one can think of three possible firm regimes (see Figure 1).10 A firm in regime 1 (D1) is characterized by low investment opportunities and sufficient retained earnings to finance all these projects. The firm's demand curve intersects with the supply curve for retained earnings. A firm in regime 3 (D3), however, is characterized by greater investment opportunities (higher investment for a given rate of return), such that the firm has to and can already bear the higher costs of issuing new shares to finance all its investment projects, after exhausting retained earnings and new debt. In both regimes, the investment level does not change in response to an unexpected increase of the firm's cash flow which shifts the supply curve to the right. Regime 2 (D2) covers financially constrained firms. These firms neither can finance all their investment projects with internal cash nor do they have so many profitable investment opportunities that they already bear the higher costs of new shares. Thus, for these firms the demand intersects with the supply curve for new debt such that a positive cash flow shock which shifts the supply curve to the right allows them to finance a greater share of their investment with retained earnings as well as the same amount with debt as before. Therefore, the amount of investment for these firms depends on the cash flow.

For analyzing the effects of corporate income taxation one has to distinguish the three regimes again. The financially unconstrained firm in regime 1 invests at the margin, where marginal costs (given by $r_{r e}$ ) equal marginal benefits. If one introduces corporate income taxation, the

\footnotetext{
${ }^{10}$ This discussion is adopted from Bond and Meghir (1994b).
} 
Figure 1: The hierarchy of finance model with debt finance

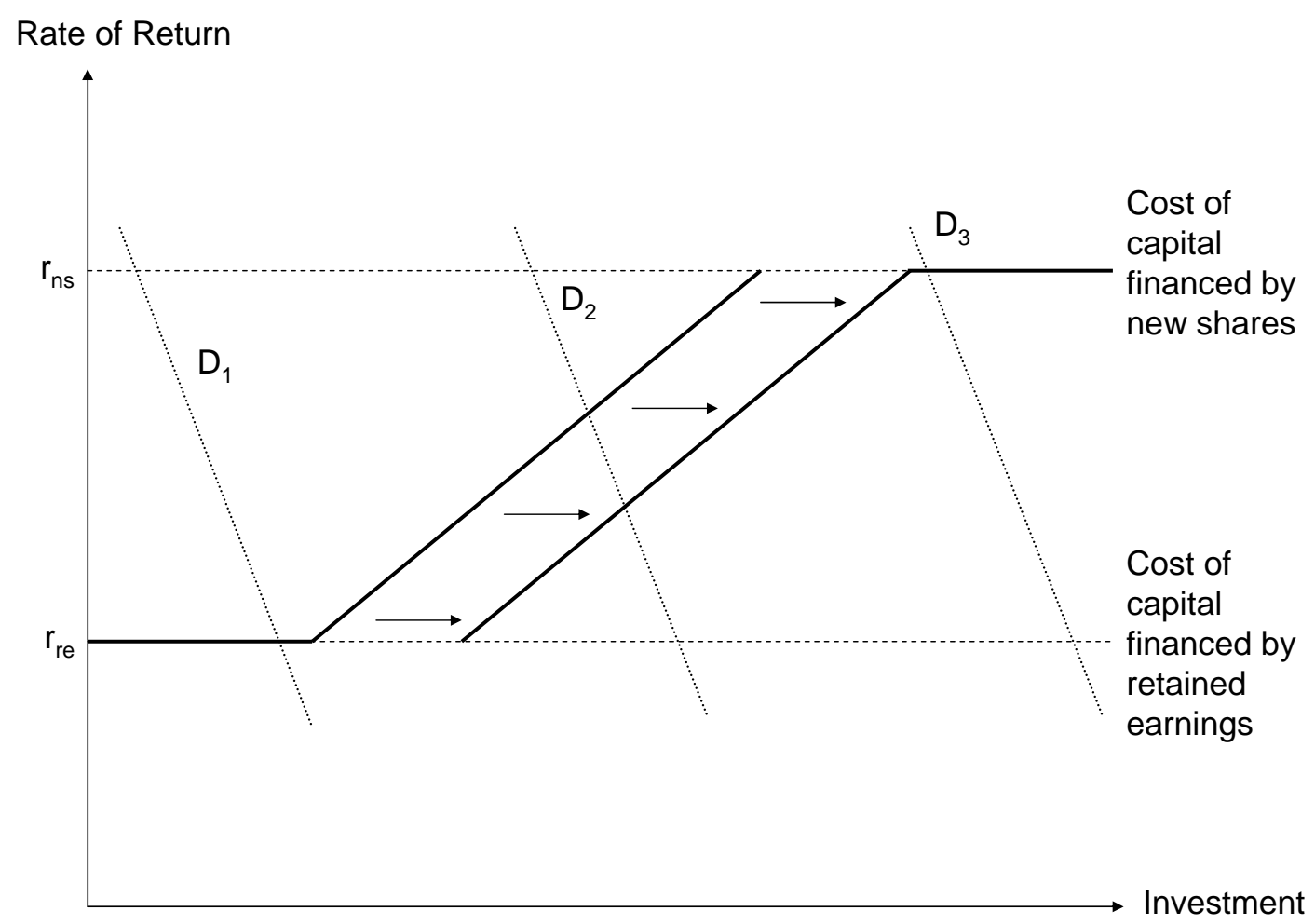

Source: Bond and Meghir (1994a)

benefit of investment at the margin is reduced by the effective marginal tax rate $(E M T R)$ the firm faces. The firm will therefore scale down its investment level from $I_{1}$ to $I_{2}$ as depicted on the left side in Figure 2. This summarizes the usual channel of how corporate income taxation affects investment. However, there could be also another effect of corporate income taxation on investment since the tax bill reduces the available cash flow of the firm. This reduction of the available cash flow through taxation can be captured by the effective average tax rate $(E A T R)$. For a better understanding, I will name in the following the latter the liquidity and the first the cost effect of taxation. For the firm in regime 1 this implies that besides the cost effect also the liquidity effect might affect investment. However, as the investment level of these firm does not depend on cash flow the liquidity aspect of taxation does not matter for investment. The same argumentation is true for firms in regime 3 , although the face higher marginal costs, their investment level is cash independent. Thus, only the EMTR but not the EATR matters 
for their investment.

Figure 2: Corporate income taxation in the hierarchy of finance model with debt finance
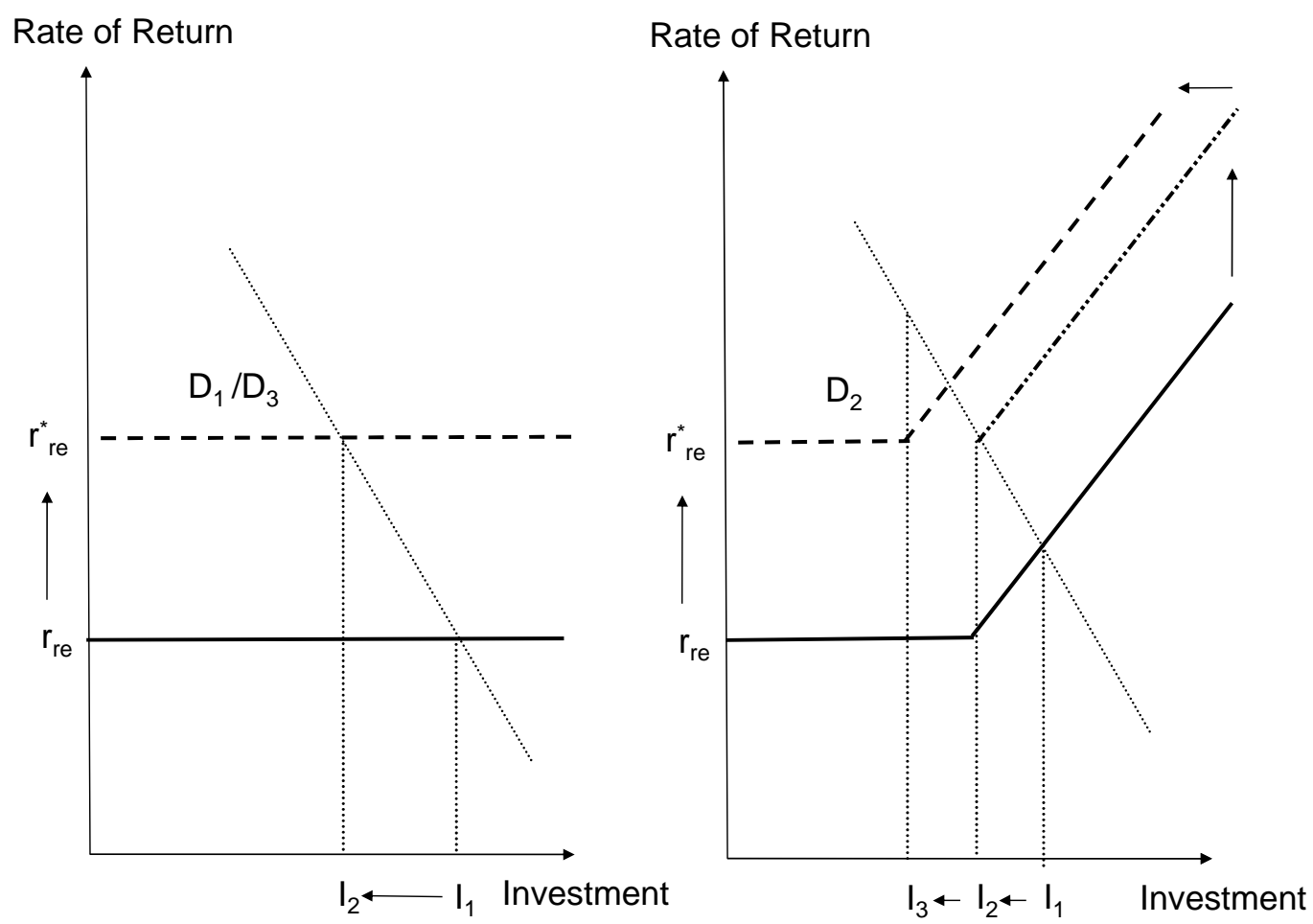

In contrast, when considering financially constrained firms (D2), for which internal and external finance are no substitutes, the liquidity aspect of corporate taxation matters. The case of financial constraints is depicted on the right hand side of Figure 2, where a firm with marginal costs $r_{r e}$ faces a external credit supply, which is increasing in the rate of return. If corporate income taxation is now introduced, cost and liquidity effect of corporate income taxation must be distinguished. Firstly, the marginal cost of investment increases from $r_{r e}$ to $r_{r e}^{*}$, as in the case without financial constraints. Thus, due to this cost channel of corporate income taxation, the investment level decreases from $I_{1}$ to $I_{2}$. Compared to the unconstrained firms, the reduction is smaller since $I_{1}$ was not optimal for the constrained firms. Secondly, introducing corporate income taxation reduces liquidity because of a higher tax bill, which is captured by the change in the EATR a firm faces. As shown on the right side of Figure 2, 
retained earnings decrease and thus a shift of the supply curve to the left is observed, which leads to an additional reduction of the investment level for the constrained firms from $I_{2}$ to $I_{3}$. In case of a vertical supply curve, the extreme case of finance constraints, only the liquidity aspect of taxation would matter for the investment decision of the constrained firm.

Thus theory suggests that the investment decision of financially unconstrained firms is dominantly affected by corporate taxation through the cost channel, which is captured by the $E M T R$, whereas the investment decision of constrained firms depends more on the liquidity aspect of taxation, expressed by the EATR the firm faces. Fazzari et al. (1988) and Bond and Meghir (1994b) were the first to discuss the effect of corporate taxation to investment under financial constraints. Keuschnigg and Ribi (2009) summarized these considerations in a theoretical model, which includes taxation in a principal agent setting with an investor and a bank.

\section{Data \& Variables}

\subsection{Data}

The panel data set I use consists of individual annual financial statements of German corporate enterprises, both publicly traded companies and corporations with limited liability (GmbH), available in the Hoppenstedt database.11 The sample period covers financial years 1987 through 2008. Before estimation, the sample was cleaned. Firms with fewer than five observations were dropped. To minimize the impact of outliers, both the top and bottom 0.5 percent of the distribution of change in turnover as well as the top and bottom 2 percent of the distribution of cash flow were trimmed (for similar trimming see, e.g., von Kalckreuth (2001). Since estimation is done in first differences, the first year of observations is also lost. Therefore, the analysis is based on a dataset comprising 25,812 annual observations for 3,929 firms.

\subsection{Variables used in the Model}

The dependent variable in the model is the investment rate, which is defined as firm-specific gross investment normalized by the replacement costs of the beginning-of-the-period capital stock $\frac{I_{i, t}}{K_{i, t-1}}$. Since the replacement costs of the capital stock are not available in the database, these are estimated using the perpetual inventory method, which is explained in detail in Appendix B.

The key variable in the neoclassical model is the user cost of capital $(U C C)$, which I construct based upon the work by Jorgenson (1963), Hall and Jorgenson (1967), and King and Fullerton

\footnotetext{
${ }^{11}$ This is the same data base as used by Dwenger (2009).
} 
(1984). The $U C C_{i, j, t}$ for firm $i$ in industry $j$ at time $t$ is the weighted average of its asset-specific user costs $U C C_{i, j, a, t}$ :

$$
U C C_{i, j, t}=\sum_{a} \kappa_{i, t}^{a} * U C C_{i, j, a, t}=\sum_{a}\left(\frac{p_{t}^{I}}{p_{t}^{S}} \frac{*\left[1-z_{t, a}\right] *\left[\theta_{t}+\delta_{j, a, t}^{e}\right]}{\left[1-\tau_{t}\right]}\right)
$$

where $\kappa_{i, t}^{a}$ is the firm-specific share of asset a to total assets, $p_{t}^{I}$ is a price deflator for investment goods at time $t, p_{j, t}^{S}$ is the industry $j$-specific output price at time $t, \delta_{j, a, t}^{e}$ is the asset $a$, industry $j$-specific economic depreciation rate, which captures the difference between physical depreciation and expected capital gains, and $z_{a, t}$ are asset $a$-specific depreciation allowances by the tax system. Two types of assets are considered, property with buildings and fixed tangible assets. The EMTR, $\tau_{t}$, captures the corporate income tax (on retained earnings) and the solidarity surcharge. Following Chirinko, Fazzari and Meyer (1999) the financial costs $\left(\theta_{t}\right)$ are the after tax interest rate of debt, which is the same for all firms in period $t .^{12}$

The second key variable for analyzing the link between corporate income taxation and financial constraints is the $E A T R_{i, t}$, which is defined as tax payments $\left(e t p_{i, t}\right)$ divided by the replacement costs of the beginning-of-the-period capital stock $\left(K_{i, t-1}\right)$. The identification of the two tax effects, EMTR and EATR, is ensured as the statutory corporate income tax rate decreased remarkably between 1987 and 2008, from 56\% to 15\%, due to tax reforms (Appendix B Table B.1). Additional explanatory variables are real sales (measured as firm-specific turnover deflated by an industry-specific output price deflator) and before tax cash flow (income before tax plus depreciation). Appendix B provides details about the construction of the variables.

\subsection{Measurement of Financial Constraints}

To assess whether corporate income taxation affects company investment decisions differently with respect to the degree of financial constraints, I identify firms that face financial constraints. For the sample splitting criteria, on the one hand, I use the dividend payout behavior (yes or no) and, on the other, the ratio of the liabilities to total assets (above and below the median per year and industry). These two criteria are based on the cash flow identity ${ }^{13}$ and are shown to

\footnotetext{
${ }^{12}$ Although it would be possible to use a weighted average of the different sources of finance, this simplification ensures that the financial costs are in line with the hierarchy of finance theory. Furthermore, the chosen financial costs do not influence the results as my estimated coefficients are identical to the one estimated in Dwenger (2009), who used a weighted average as financial costs.

${ }^{13}$ Investment + Dividend $<$ Cash flow + Change in liabilities + New shares. Assuming a marginal benefit of paying out dividends, an unconstrained firm has no incentive not to payout dividends, since internal finance is not decisive for the investment decision. However, if a firm is constrained, it is very unlikely that it will payout dividends since this would reduce the investment level further. Nonetheless, one should keep in mind that firms in certain industries tend not to pay dividends (von Eije and Megginson (2008)). The reasons for this development are still unclear. The use of liabilities as an indicator of financial constraints is based
} 
be a good indicator for financial constraints in other studies, as direct sample splitting criteria (Fazzari et al. (1988), Bond and Meghir (1994a), Behr and Bellgardt (2000) ) or at least as one important factor for the likelihood of being constrained or not (Hovakimian and Titman (2006), Almeida and Campello (2007)). However, since firms have, in principle, three possible ways to finance investment (retained earnings, debt and new equity), one must account for firms issuing new shares. These firms could decide not to pay any dividends (or have a high ratio of liabilities) and would therefore be classified as financially constrained even though the firm is not actually constrained since it uses the most expensive source of finance according to the hierarchy of finance theory (Myers (1984)). In order to account for these cases, a firm is reclassified to be financially unconstrained if it issues/issued new shares in the present or last period 14 .

This procedure also addresses the issue of internal financially constrained firms showing negative cash flow sensitivity, which might be included in the data and would then bias the estimated cash flow coefficient. While this is not very likely, since these firms are even smaller and younger than external financially constrained firms, as shown by Hovakimian (2009), and because my data contains mostly large companies, the reclassification ensures that these firms would be considered as unconstrained as they usually issue new shares because of their profitable investment opportunities.

According to the dividend payout behavior sample splitting criterion(see Appendix A. Table A.1 and Table A.2), the share of constrained firms varies between 29 and $70 \%$ (excluding fishery) for the different industries; the mean is about 40\%. The share of constrained firms by year starts at $32 \%$ in 1991 and increases to $49 \%$ in 1998. After a decline to $10 \%$ in 2002, an increase to $55 \%$ in 2007 is observed. For the ratio of liabilities to total assets as splitting criterion, the distribution of financially constrained firms by years is very similar. For 1992, 33\% of all firms are financially constrained, slightly increasing to $37 \%$ in 1998, followed by a decrease to $6 \%$ in 2002 and then up to $36 \%$ in 2008 . The share of financially constrained firms by industry varies between 27 and $40 \%$ (without Fishery), with a mean of $31 \%$ for the whole sample.

The characteristics of the split sample, according to dividend payout behavior, differ noticeably (see Appendix A, Table A.4 and Table A.5). Constrained firms are smaller (mean capital stock 248 Mill. versus 331 Mill. Euros), invest less (on average 7\% versus 14\%) and have, on average, a lower cash flow (on average $29 \%$ versus $40 \%$ of the capital stock). Additionally, the $E A T R$ is much lower for constrained firms (mean $7 \%$ to $13 \%$ ). However, the distribution of the $U C C$ is similar for both groups.

on the argumentation that a higher debt level leads to higher marginal costs of finance due to bankruptcy costs. Cleary et al. (2007) named this the costs effect.

${ }^{14}$ This is comparable to the procedure used by van Binsbergen et al. (2010) 
The characteristics of financially constrained firms, according to the splitting criterion ratio of bank liabilities to total assets, are similar to those described above (see Appendix A, Table A.6 and Table A.7). These firms are slightly smaller (on average capital stock 278 Mill. versus 309 Mill Euros), invest less (on average 7\% versus 13\% of the capital stock) and have a lower cash flow (on average $23 \%$ versus $36 \%$ of the capital stock). Furthermore, the EATR is lower for constrained firms (mean 9\% versus 12\%).

\section{Model \& Methodology}

As pointed out in the introduction one of the main critiques of prior studies analyzing financial constraints is the lack of accounting for self-selection (e.g. Chatelain(2003)), which might result in biased estimates if there are truly different regimes. This is also true in case of estimation in first differences since firms may switch between the the regimes and thus the selection bias does not cancel out. Therefore, this study accounts directly for the selection process by using a switching regression framework with known sample seperation. Theory on self-selection originates with Roy (1951) and is developed further by Maddala and Nelson (1974) and Maddala (1986). The starting point for the switching regression is the assumption that the number of regimes is known. Two different regimes are assumed, one for the financially constrained and one for unconstrained firms. For both regimes there is a structural equation (equation (2) resp. (3)), which could, but do not have to, include the same variables. Furthermore, there is a selection equation (4) that determines a firm's propensity of being in regime 1 or 2 .

$$
\begin{gathered}
I_{i, t}=X_{i, t} * \beta_{1}+u_{1, i, t} \quad \text { if } \quad y_{i, t}^{*} \geq 0 \\
I_{i, t}=X_{i, t} * \beta_{2}+u_{2, i, t} \quad \text { if } \quad y_{i, t}^{*}<0 \\
y_{i, t}^{*}=Z_{i, t} * \gamma+\epsilon_{i, t}
\end{gathered}
$$

In the structural equations (2) and (3), $X_{i, t}$ are the determinants of corporate investment and $Z_{i, t}$ are the determinants of a firm's likelihood of being in the first or the second regime. $\beta_{1}, \beta_{2}$ and $\gamma$ are parameter vectors, $y_{i, t}^{*}$ is a latent variable measuring whether a firm is financially constrained or not. A switch between the two regimes is possible and occurs in case $y_{i, t}^{*}$ reaches a certain (unobserved) threshold value. The error terms of equation (2), (3), and (4) are assumed to be normally distributed with mean 0 . In case of estimating the structural equations separately without accounting for the self-selection into the two regimes, the estimated 
coefficients will only be unbiased if the error terms of the structural equation $u_{1, i, t}$ and $u_{2, i, t}$ are uncorrelated with the error term of the selection equation $\epsilon_{i, t}$. Otherwise the estimation suffers from a selection bias, which can be interpreted as an omitted variable bias 5 . However, in contrast to unknown sample separation in case of known sample separation, the latent variable $y_{i, t}^{*}$ is observed. This makes estimation much easier since the system of equations does not have to be estimated simultaneously, but can instead be estimated as two two-stage standard Heckman-type self-selection models (Heckman (1979)).

Following Heckman (1979), in the first step, I estimate the selection equation using maximum likelihood to calculate the selection term, the inverse Mills ratio, which is the ratio of the probability density and the cumulative density function. In the second step, the estimated inverse Mills ratio is included in the structural equations and the investment equations are estimated.

Determinants of the firm's likelihood to be in regime 1 or 2 (summarized by $Z_{i, t}$ in Equation (4)) are chosen following the existing literature ${ }^{16}$. For the selection equation based on dividend payout as splitting criterion I include the following variables:

Firm size: Smaller firms are more likely to be financially constrained for several reasons. Firstly, transaction costs are mostly fixed costs which make external finance relatively more expensive for smaller firms. Secondly, small firms are less often rated and thus suffer more from informational asymmetries between lender and borrower. Furthermore, a third reasons for a greater likelihood is the greater risk of bankruptcy for smaller firms due to less diversification when compared to larger firms. Although the results of Audretsch and Elston (2002) contradict these considerations for Germany as they find middle sized firms are more likely to be financially constrained, I still expect them to be valid. Following Schiantarelli (1995), its very likely that the results of Audretsch and Elston (2002) are due to their small sample of quoted firms. Thus, I expect for my dataset, which captures quoted and unquoted firms and also covers a broader spectrum of the size distribution, that smaller firms are more likely to be financially constrained for the above mentioned reasons. I measure firm size as the natural logarithm of the book value of total assets.

Short and Long Term Debt: As summarized by Lang, Ofek and Stulz (1996), the debt ratio my affect negatively investment because it reduces the available cash. To account for possible difference due to the maturity of the debt I include both the ratio of short term and of long term debt to total assets.

Financial Slack: Financial slack may indicate a greater or a lesser likelihood of being

\footnotetext{
$\left.\overline{{ }^{15} E\left[I_{i, t} \mid y_{i, t}^{*}>0\right]=X_{i, t} * \beta_{1}+E\left[u_{i, t} \mid y_{i, t}^{*}>0\right.}\right]$ with $E\left[u_{i, t} \mid y_{i, t}^{*}>0\right]=E\left[\sigma_{1, \epsilon} * \epsilon \mid \epsilon<Z_{i, t} * \gamma\right]=\sigma_{1, \epsilon} * \frac{\phi\left(Z_{i, t}\right) * \gamma}{\Phi\left(Z_{i, t} * \gamma\right)}$ ${ }^{16}$ See for example Hovakimian and Titman (2006), Almeida and Campello 2007).
} 
financial constrained. Some argued that firms with large cash reserves are not financially constrained as their investment is not constrained by a lack of finance ${ }^{17}$ However, on the other hand, it is stated that constrained firms have a higher incentive to accumulate cash ${ }^{18}$. Since both arguments are plausible, I have no clear expectation about the relationship of financial slack and the likelihood of being financially constrained. I define the variable as cash plus liquid securities scaled by the beginning-of-the-period capital stock.

Tangibility: Like Almeida and Campello (2007), I include a measure of the tangibility of the firms' assets in the selection equation since firms with a high share of tangible assets have a higher liquidation value and thus have easier access to external capital market. Due to missing information for the calculation of the tangibility of a firm, I define tangibility as the share of tangible assets to total assets.

Dummy for Publicly Traded Firms: Furthermore, I include a dummy variable for publicly traded firms, as these firms have easier access to equity capital and are thus expected to be less likely financially constrained.

EATR: In addition, I include the EATR as I expect that firms with higher tax bills might by more likely to be financially constrained. The $E A T R$ is measured as tax payments normalized by the replacement costs of the beginning-of-the-period capital stock.

For the share of liabilities to total assets, I include, like for the first splitting criterion, Firm size, Financial Slack, Tangibility, a Dummy for Publicly Traded Firms and the EATR. In addition, instead of the two leverage variables, I include a dummy for Dividend Payout. For both splitting criteria, all the variables enter the equation in lagged form. The exclusion restriction for identification of the inverse Mills ratios is ensured since the structural approach of the outcome equation determines which variables to include in the investment equation. Thus, i.e. Firm size and Financial Slack does not affect investment but the likelihood whether a firm is constrained or not.

The determinants of the structural equations (captured by $X_{i, t}$ in equation (2) resp. (3)) for both regimes are based on the neoclassical approach (Jorgenson (1963), Eisner and Nadiri (1968) and Arrow, Chenery, Minhas and Solow (1961)). Following the procedure used by Chirinko et al. (1999), the ADL investment model is given by equation (5), where the left-hand side variable is the investment rate, $\triangle s_{i, t}$ the growth rate of sales, $\triangle u c c_{i, t}$ the growth rate of the $U C C$ and $\xi_{i, t}$ an error term. The error term has the same properties as $u_{1, i, t}$ and $u_{2, i, t}$ in equation (2) resp. (3). For comparability with prior results in the literature I start my analysis by including after tax cash flow as a measure of internal finance in the equation as Fazzari et al. (1988) and Fazzari et al. (2000).

\footnotetext{
${ }^{17}$ For example Kaplan and Zingales (1997).

${ }^{18}$ For example Fazzari, Hubbard and Petersen 2000).
} 


$$
\begin{aligned}
\frac{I_{i, t}}{K_{i, t-1}} & =\delta+\sum_{h=0}^{H} \beta_{h} \triangle s_{i, t-h}-\sum_{h=0}^{H} \sigma_{h} \triangle u c c_{i, t-h}+\theta_{c f-e a t r} \frac{C F_{i, t}-e t p_{i, t}}{K_{i, t}}+\xi_{i, t} \\
\frac{I_{i, t}}{K_{i, t-1}} & =\delta+\sum_{h=0}^{H} \beta_{h} \triangle s_{i, t-h}-\sum_{h=0}^{H} \sigma_{h} \triangle u c c_{i, t-h}+\theta_{c f} \frac{C F_{i, t}}{K_{i, t}}-\theta_{e t r} \frac{e t p_{i, t}}{K_{i, t}}+\omega_{i, t}
\end{aligned}
$$

For analyzing the effects of corporate income taxation, tax adjusted cash flow and the EATR instead of after tax cash flow is included, as shown in equation (6). As discussed in Section 2. the long term coefficient for the $U C C,\left(\sum \sigma_{h}\right)$ should be lower for financially constrained firms than for unconstrained firms, whereas for the coefficient of the EATR $\left(\theta_{\text {etr }}\right)$ the opposite should be true.

Estimation of the structural equation is done using an instrumental variable technique for the $U C C$, the EATR, turnover and cash flow. The $U C C$ is instrumented for following reasons: First, since measurement error is likely to occur $[19$, the coefficient of the user costs of capital in an OLS regression would be biased toward zero, as shown by Goolsbee (2000). Second, the user costs of capital might be endogenous since a firm's asset structure used as weighting of the UCC is probably correlated with investment. Third, with an upward sloping curve for capital supply, a reduction in the tax rate raises prices in the short run and thus might attenuate the increase in investment through reduced taxes (Goolsbee (1998), Goolsbee (2004)). This simultaneity bias also distorts the user costs elasticity towards zero. Additionally, simultaneity of investment shocks and interest rate might bias the user costs of capital coefficient as suggested by Chirinko et al. (1999). The EATR, turnover, and cash flow are also instrumented since all variables are very likely to be contemporaneously correlated with investment; additionally measurement error is likely to occur.

The estimation technique is a two stage least squares regression. As instruments the lagged changes in the growth rate of the user costs of capital, sales and lagged cash flow and lagged $E A T R$ is used. To check the quality of the instruments, the Sargan test of over-identifying restrictions and Shea's Partial $R^{2}$ of the first stage regressions are reported, as suggested by Shea (1997) and Godfrey (1999) ${ }^{20}$ Additionally, heteroscedasticity-consistent robust (HuberWhite) standard errors are reported ${ }^{21}$

\footnotetext{
${ }^{19}$ Measurement error is likely to occur because for example economic depreciation is not firm but industry specifically considered in the construction of the user costs of capital.

${ }^{20}$ Sargan-test for overidentifying restriction can be used to check for the exogeneity of the instruments, whereas Partial $R^{2}$ can be used to check the relevance of the instruments.

${ }^{21}$ Although the two-step estimation procedure requires bootstrapped standard errors since the inverse Mills ratios are estimated in the first step, I only show the Hubert-White standard errors in the results section, as excluding the inverse Mills ratio does not change my results and even with bootstrapped standard errors, the level of significance for my coefficients of interest did not change remarkably.
} 


\section{Results}

The results of the estimated selection equation, according to dividend payout behavior as sample splitting criterion, are reported in Table 1 . The results reveal that firms paying no dividends and issuing no new shares, thus classified as financially constrained, are - as expected - smaller, have higher debt ratios (both short and long term), are less likely to be publicly traded and have a lower share of tangible assets ${ }^{22}$ Concerning EATR, the results show that constrained firms pay less in taxes and that these firms have a lower share of financial slack, which contrasts with the findings for US corporations (Hovakimian and Titman (2006), Almeida and Campello (2007)) and supports the view of Kaplan and Zingales (1997) who argue that firms with large cash reserves are not constrained by a lack of finance.

Table 1: Selection equation: dividend payout as sample splitting criterion

\begin{tabular}{lrc}
\hline & Coeff. & SE \\
\hline Firmsize & -0.074 & $(0.005)^{* * *}$ \\
Short Term Debt & 0.354 & $(0.047)^{* * *}$ \\
Long Term Debt & 0.189 & $(0.046)^{* * *}$ \\
Dummy Publicly Traded & -0.601 & $(0.022)^{* * *}$ \\
Financial Slack & -0.941 & $(0.063)^{* * *}$ \\
Tangibility & -0.187 & $(0.038)^{* * *}$ \\
EATR & -0.019 & $(0.005)^{* * *}$ \\
\hline Observations & 25,812 & \\
p-value of the model (likelihood ratio test) & 0.000 & \\
\hline
\end{tabular}

Notes: Dependent variable is coded as 1 for investment regime 1 and 0 for investment regime 2. Firms assigned into regime 1 are classified as financially constrained; regime 2 covers the financially unconstrained firms. Variables defined as described in the text. $*, * *, * * *$ indicate significance at the 10,5 and 1 percent two-tail test levels, respectively.

Source: Hoppenstedt firm database and own calculations.

For comparability with prior studies, I estimate the neoclassical investment model with after tax cash flow for all firms together and with the switching regression approach for the two subsamples. The validity of the instruments is given (see Appendix A, Table A.8) ${ }^{23}$ The estimated coefficients for the whole and the two sub samples are reported in Table 2.

The estimated cash flow coefficient for the whole sample is similar to previous findings. After accounting for the different investment regimes, the cash flow coefficient increases to 0.16 for financially constrained firms and falls to 0.09 for unconstrained firms, as theory predicts. However, all three coefficients are significant at the $1 \%$ level, although I expected the effect

\footnotetext{
${ }^{22}$ These results highlight as well that using a $q$-based approach is likely to exclude financially constrained firms.

${ }^{23}$ With exception of the investment equations for constrained firms, Sargan test for valid instruments cannot be rejected at the $10 \%$ level. Additionally the instruments are well correlated with the regressors, the minimum Shea's partial $R^{2}$ is 0.15 .
} 
of cash flow for unconstrained firms to vanish. This could be due to the imperfect a priori sample splitting, which does not account for the multifactorial reasons of financial constraints. If cash flow is a proxy for future profitability, this might also explain a significant cash flow effect (Bond, Harhoff and van Reenen (2003a)).

Table 2: Investment and cash flow sensitivity: dividend payout as splitting criterion

\begin{tabular}{lcccccc}
\hline & \multicolumn{2}{c}{ All firms } & \multicolumn{2}{c}{ Unconstrained firms } & \multicolumn{2}{c}{ Constrained firms } \\
& Coeff. & SE & Coeff. & SE & Coeff. & \multicolumn{1}{c}{ SE } \\
\hline$\triangle u c c_{i, t}$ & -0.318 & $(0.077)^{* * *}$ & -0.435 & $(0.130)^{* * *}$ & -0.157 & $(0.045)^{* * *}$ \\
$\triangle u c c_{i, t-1}$ & -0.174 & $(0.055)^{* * *}$ & -0.241 & $(0.085)^{* * *}$ & -0.077 & $(0.055)$ \\
$\triangle u c c_{i, t-2}$ & -0.140 & $(0.054)^{* * *}$ & -0.203 & $(0.083)^{* *}$ & -0.046 & $(0.049)$ \\
$\triangle$ ucc $_{i, t-3}$ & -0.052 & $(0.039)$ & -0.098 & $(0.062)$ & 0.012 & $(0.034)$ \\
$\triangle$ sales $_{i, t}$ & 0.229 & $(0.040)^{* * *}$ & 0.244 & $(0.055)^{* * *}$ & 0.204 & $(0.046)^{* * *}$ \\
$\triangle$ sales $_{i, t-1}$ & 0.061 & $(0.031)^{*}$ & 0.062 & $(0.030)^{* *}$ & 0.058 & $(0.068)$ \\
$\left(\right.$ cf $_{i, t}-$ etp $\left._{i, t}\right) / K_{i, t-1}$ & 0.099 & $(0.021)^{* * *}$ & 0.086 & $(0.025)^{* * *}$ & 0.158 & $(0.038)^{* * *}$ \\
$\lambda(0)$ & & & 0.226 & $(0.109)^{* *}$ & & \\
$\lambda(1)$ & & & & & -0.106 & $(0.051)^{* *}$ \\
Intercept & 0.094 & $(0.037)^{* *}$ & 0.044 & $(0.061)$ & 0.112 & $(0.084)$ \\
\hline Observations & 25,812 & & 15,585 & & 10,227 & \\
Eucc & -0.684 & $(0.209)^{* * *}$ & -0.977 & $(0.336)^{* * *}$ & -0.268 & $(0.166)$ \\
\hline
\end{tabular}

Notes: The dependent variable is investment scaled by the replacement costs of the beginning-of-the-period capital stock. Constrained firms are firms that do not pay dividends and do not issue new shares in the present and the last period. Unconstrained firms either pay a dividend or issue new shares in the present or in the last period. All models are estimated using two stage least squared regression. The variables, except the selection terms, are instrumented with the change of the growth rate of the $U C C$, change of growth rate of turnover and twice lagged cash flow. ${ }^{*}, * *, * * *$ indicate significance at the 10,5 and 1 percent two-tail test levels, respectively. T-statistic and significance are based on heteroscedasticity-robust standard errors. The standard errors for the long-term coefficient of the user costs of capital are calculated using the delta method.

Source: Hoppenstedt firm database and own calculations.

The long term coefficient of the $U C C$ for all firms (-0.68) is comparable to previously documented results using an ADL model (von Kalckreuth (2001), Harhoff and Ramb (2001), Dwenger (2009)). If I now account for the two investment regimes and the self-selection process, the long term coefficient for the $U C C$ for financially unconstrained firms increases to -0.98 , significant at the $1 \%$ level, and decreases for financially constrained firms to -0.27 and becomes insignificant. These results are in line with my theoretical prediction and suggest that firms facing financial constraints react less to changes in the costs of investment through changes in the corporate income tax rate because they are constrained by their financial situation.

In addition, the estimated long term coefficient of the $U C C$ for financially unconstrained firms is comparable to what is found by Dwenger (2009) using an error correction model (ECM) (long-term UCC of -0.93) or by Buettner and Hoenig (2011) (long-term UCC of -1.07) using a partial adjustment approach. Firstly, this indicates that the elasticity of capital to its 
user costs in an ADL model is underestimated in case of neglecting the presence of financial constraints, which confirms the results of Chirinko and von Kalckreuth (2003). Secondly, the results seems to suggest that models like the ECM oder the partial adjustment model do not suffer from the lack of consideration of financial constraints. The reason for this could be that these models explicitly rely on the long term relationship between the $U C C$ and the capital stock, whereas in ADL models the long term relationship is merely the sum of the short term effects. This would be in line with the findings by Hovakimian and Hovakimian $(2009)$, who showed that financially constrained firms underinvest in bad cash flow years and overinvest in good cash flow year. Thus in the long run financially constrained firms react to price changes as unconstrained firms.

As a last point, it is worth noting that the inverse Mills ratios are significant, which indicate that the error term of the selection equation is correlated with the error terms of the structural equation. Thus, without accounting for the self selection process, the coefficients of the investment equation would be biased. However, in a robustness check I exclude the inverse Mills ratios and the results do not change significantly. Thus, the bias due to the selection issue seems to be less important.

The results for the sensitivity of the EATR are presented in Table 3. As expected, the long-term coefficient for the $U C C$ remains unchanged. Furthermore, similarly to cash flow in the model above, tax payment adjusted cash flow is significant for both groups, but more than twice as large for financially constrained firms (0.16 compared to 0.07). Thus it remains unclear whether cash flow for unconstrained firms is significant because it is a proxy for future profitability or because of the incomplete a priori sample splitting.

With respect to the $E A T R$ sensitivity, the results prevail that for financially unconstrained firms the liquidity aspect of taxation does not matter (insignificant EATR coefficient of -0.044) although these firms pay higher taxes (see Appendix A. Table A.4 and Table A.5). In contrast, as I expected based on the theoretical considerations, an increase of the EATR by 10 percentage points decreases investment by around 1.6 percentage points for financially constrained firms through the reduction of internal finance.

Thus the results show that firms which pay no dividends and issue no new shares and are thus classified as financial constraints in this study, react less to changes in the EMTR and more to changes in the EATR. For unconstrained firms, the reverse is true. For these firms, the estimated elasticity of capital to its $U C C$ is around -1 . Hence, corporate income taxation affects firms investment decision differently according to the degree of financial constraints the firm faces. The stronger the degree of finance constraints, the stronger the influence through the $E A T R$, the lower the degree the stronger the effect of the EMTR.

The results for the switching regression for the debt ratio as splitting criterion (Table 4) 
Table 3: Investment and EATR sensitivity: dividend payout as splitting criterion

\begin{tabular}{lcccc}
\hline & \multicolumn{2}{c}{ Unconstrained firms } & \multicolumn{2}{c}{ Constrained firms } \\
& Coeff. & SE & Coeff. & SE \\
\hline$\triangle u c c_{i, t}$ & -0.435 & $(0.130)^{* * *}$ & -0.157 & $(0.045)^{* * *}$ \\
$\triangle u c c_{i, t-1}$ & -0.242 & $(0.086)^{* * *}$ & -0.078 & $(0.055)$ \\
$\triangle u c c_{i, t-2}$ & -0.202 & $(0.083)^{* *}$ & -0.047 & $(0.049)$ \\
$\triangle u c c_{i, t-3}$ & -0.097 & $(0.062)$ & 0.012 & $(0.034)$ \\
$\triangle$ sales $_{i, t}$ & 0.244 & $(0.055)^{* * *}$ & 0.203 & $(0.046)^{* * *}$ \\
$\triangle$ sales $_{i, t-1}$ & 0.059 & $(0.030)^{*}$ & 0.057 & $(0.068)$ \\
$c f_{i, t} / K_{i, t-1}$ & 0.074 & $(0.025)^{* * *}$ & 0.160 & $(0.042)^{* * *}$ \\
EAT $_{i, t}$ & -0.044 & $(0.050)$ & -0.164 & $(0.054)^{* * *}$ \\
$\lambda(0)$ & 0.212 & $(0.102)^{* *}$ & & \\
$\lambda(1)$ & & & -0.103 & $(0.050)^{* *}$ \\
Intercept & 0.054 & $(0.058)$ & 0.108 & $(0.085)$ \\
\hline Observations & 15,585 & & 10,227 & \\
Iucc & -0.977 & $0.336^{* * *}$ & -0.270 & 0.164 \\
\hline
\end{tabular}

Notes: The dependent variable is investment scaled by the replacement costs of the beginning-of-the-period capital stock. Constrained firms are firms that do not pay dividends and do not issue new shares in either the present or the last period. Unconstrained firms either pay a dividend or issue new shares in the present or in the last period. All models are estimated using two stage least squared regression. The variables, except the selection terms, are instrumented with the change of the growth rate of the $U C C$, change of growth rate of turnover and twice lagged cash flow and twice lagged EATR.*, **, *** indicate significance at the 10, 5 and 1 percent two-tail test levels, respectively. T-statistic and significance are based on heteroscedasticity-robust standard errors. The standard errors for the long-term coefficient of the user costs of capital are calculated using the delta method.

Source: Hoppenstedt firm database and own calculations.

Table 4: Selection equation: debt ratio as splitting criterion

\begin{tabular}{lrc}
\hline & Coeff. & SE \\
\hline Firm size & -0.043 & $(0.005)^{* * *}$ \\
Tangibility & 0.300 & $(0.032)^{* * *}$ \\
EATR & -0.001 & $(0.005)$ \\
Dummy Publicly traded & -0.357 & $(0.023)^{* * *}$ \\
Dummy Dividend Payout & -0.250 & $(0.018)^{* * *}$ \\
Financial Slack & -1.125 & $(0.068)^{* * *}$ \\
\hline Observations & 25,812 & \\
p-value of the model (likelihood ratio test) & 0.000 & \\
\hline
\end{tabular}

Notes: Dependent variable is coded as 1 for investment regime 1 and 0 for investment regime 2. Firms assigned into regime 1 are classified as financially constrained; regime 2 covers the financially unconstrained firms. Variables defined as described in the text. $*, * *, * * *$ indicate significance at the 10,5 and 1 percent two-tail test levels, respectively.

Source: Hoppenstedt firm database and own calculations.

are similar to the findings described above. They indicate that financially constrained firms are smaller, are less often publicly traded and are less likely to pay dividends. In addition, financially constrained firms have lower cash reserves. With respect to the $E A T R$, financially 
constrained and unconstrained firms do not seem to differ. The link between the tangibility of firms' assets and the likelihood of a firms to be financially constrained is opposite of what I expected. However, this might be due to the fact that the debt ratio is my indicator for the financial situation of the firms. And firms with a large share of tangible assets have higher debt ratios due to their higher liquidation value.

Table 5: Investment and cash flow sensitivity: debt ratio as splitting criterion

\begin{tabular}{lcccccc}
\hline & \multicolumn{2}{c}{ All firms } & \multicolumn{2}{c}{ Unconstrained firms } & \multicolumn{2}{c}{ Constraiend firms } \\
& Coeff. & SE & Coeff. & SE & Coeff. & \multicolumn{1}{c}{ SE } \\
\hline$\triangle u c c_{i, t}$ & -0.318 & $(0.077)^{* * *}$ & -0.392 & $(0.116)^{* * *}$ & -0.189 & $(0.078)^{* *}$ \\
$\triangle u c c_{i, t-1}$ & -0.174 & $(0.055)^{* * *}$ & -0.238 & $(0.080)^{* * *}$ & -0.051 & $(0.064)$ \\
$\triangle u c c_{i, t-2}$ & -0.140 & $(0.054)^{* * *}$ & -0.172 & $(0.073)^{* *}$ & -0.075 & $(0.069)$ \\
$\triangle u c c_{i, t-3}$ & -0.052 & $(0.039)$ & -0.087 & $(0.057)$ & 0.017 & $(0.038)$ \\
$\triangle$ sales $_{i, t}$ & 0.229 & $(0.040)^{* * *}$ & 0.228 & $(0.044)^{* * *}$ & 0.234 & $(0.081)^{* * *}$ \\
$\triangle$ sales $_{i, t-1}$ & 0.061 & $(0.031)^{*}$ & 0.067 & $(0.033)^{* *}$ & 0.012 & $(0.086)$ \\
$\left(c f_{i, t}-\right.$ etp $\left._{i, t}\right) / K_{i, t-1}$ & 0.099 & $(0.021)^{* * *}$ & 0.068 & $(0.014)^{* * *}$ & 0.210 & $(0.087)^{* *}$ \\
$\lambda(0)$ & & & 0.006 & $(0.055)$ & & \\
$\lambda(1)$ & & & & & -0.077 & $(0.097)$ \\
Intercept & 0.094 & $(0.037)^{* *}$ & 0.121 & $(0.057)^{* *}$ & 0.118 & $(0.092)$ \\
\hline Observations & 25,812 & & 17,870 & & 7,942 & \\
$\sum$ M $u c c$ & -0.684 & $0.209^{* * *}$ & -0.889 & $0.307^{* * *}$ & -0.299 & 0.215 \\
\hline
\end{tabular}

Notes: The dependent variable is investment scaled by the replacement costs of the beginning-of-the-period capital stock. Constrained firms are firm that have a ratio of liabilities to total assets above the median and do not issue new shares in the present or last period. Unconstrained firms either have a ratio of liabilities below the median or issue new shares in the present or in the last period. All models are estimated using two stage least squared regression. The variables, except the selection terms, are instrumented with the change of the growth rate of the $U C C$, change of growth rate of turnover and with twice lagged cash flow. $*, * *, * * *$ indicate significance at the 10,5 and 1 percent two-tail test levels, respectively. T-statistic and significance are based on heteroscedasticity-robust standard errors. The standard errors for the long-term coefficient of the user costs of capital are calculated using the delta method.

Source: Hoppenstedt firm database and own calculations.

The results of the neoclassical investment equation with after tax cash flow for the whole sample and the two subsamples are reported in Table 5. Again, the instruments are valid (see Appendix A, Table A.9). The aspect of the long term coefficient for the $U C C$ remains unchanged, although the statistically significant long term coefficient of the UCC for the financially unconstrained firms is slightly smaller than for dividend payout as splitting criterion. For the cash flow coefficient, however, the results are stronger than for the first splitting criterion. For the whole sample the coefficient amounts to 0.1. But if I account for the different investment regimes the coefficient decreases for unconstrained firms to 0.07 and increases for constrained firms to 0.21 . All three cash flow coefficients are significant at the $5 \%$ level.

The selection terms are insignificant for liabilities as splitting criterion, which indicate that for debt ratio as proxy for the financial situation, the selection equation and the investment 
equation are independent of each other. This could be due to incomplete a priori sample splitting criteria or due to the fact that indeed the both equations are uncorrelated.

Table 6: Investment and EATR sensitivity: debt ratio as splitting criterion

\begin{tabular}{lcccc}
\hline & \multicolumn{3}{c}{ Unconstrained firms } & \multicolumn{2}{c}{ Constraiend firms } \\
& Coeff. & SE & Coeff. & SE \\
\hline$\triangle u c c_{i, t}$ & -0.386 & $(0.113)^{* * *}$ & -0.193 & $(0.080)^{* *}$ \\
$\triangle u c c_{i, t-1}$ & -0.230 & $(0.077)^{* * *}$ & -0.055 & $(0.066)$ \\
$\triangle u c c_{i, t-2}$ & -0.163 & $(0.070)^{* *}$ & -0.079 & $(0.070)$ \\
$\triangle u c c_{i, t-3}$ & -0.080 & $(0.054)$ & 0.013 & $(0.039)$ \\
$\triangle$ sales $_{i, t}$ & 0.228 & $(0.044)^{* * *}$ & 0.222 & $(0.076)^{* * *}$ \\
$\triangle$ sales $_{i, t-1}$ & 0.064 & $(0.033)^{*}$ & 0.012 & $(0.086)$ \\
$c f_{i, t} / K_{i, t-1}$ & 0.051 & $(0.016)^{* * *}$ & 0.222 & $(0.095)^{* *}$ \\
EAT $_{i, t}$ & -0.012 & $(0.044)$ & -0.273 & $(0.137)^{* *}$ \\
$\lambda(0)$ & 0.004 & $(0.054)$ & & \\
$\lambda(1)$ & & & -0.066 & $(0.093)$ \\
Intercept & 0.127 & $(0.058)^{* *}$ & 0.107 & $(0.089)$ \\
\hline Observations & 17,870 & & 7,942 & \\
Eucc & -0.859 & $(0.295)^{* * *}$ & -0.314 & $(0.222)$ \\
\hline
\end{tabular}

Notes: The dependent variable is investment scaled by the replacement costs of the beginning-of-the-period capital stock. Constrained firms are firms that have a ratio of liabilities to total assets above the median and do not issue new shares in the present or last period. Unconstrained firms either have a ratio of liabilities below the median or issue new shares in the present or in the last period. All models are estimated using two stage least squared regression. The variables except the selection term are instrumented with the change of the growth rate of the UCC, change of growth rate of turnover and with lagged cash flow and twice lagged $E A T R .{ }^{*},{ }^{* *}, * * *$ indicate significance at the 10, 5 and 1 percent two-tail test levels,respectively. T-statistic and significance are based on heteroscedasticity-robust standard errors. The standard errors for the long-term coefficient of the user costs of capital are calculated using the delta method.

Source: Hoppenstedt firm database and own calculations.

The findings for the EATR sensitivity are again similar to the results for the first splitting criterion (Table 6). The cash flow coefficient for financially constrained firms is four times larger (0.22) than for unconstrained firms (0.05) and the long term coefficient of the $U C C$ for unconstrained firms $(-0.86)$ is almost three times as larger as for constrained firms $(-0.31)$. In addition, also for the EATR the results hold. Whereas for unconstrained firms the coefficient is statistically not different from zero, for constrained firms the coefficient amounts to 0.273. This indicates an even stronger effect than for dividend payout as splitting criteria.

Thus, the results of debt ratio as splitting criterion confirm substantially the results of the first splitting criterion. The effect of corporate income taxation is different for firms that face financial constraints and those do not face these constraints. The stronger the degree of financial constraints a firm face the more relevant is the liquidity aspect of taxation, thus the $E A T R$, and the less relevant the cost channel of taxation, the EMTR. 


\section{Conclusion}

To the best of my knowledge, this study is the first that examines the different effects of corporate income taxation on investment with and without binding financial constraints. From a theoretical point of view I expect that the investment decision of financially unconstrained firms depends on the $E M T R$, which captures the normally assumed cost channel of corporate taxation. However, the EATR, which measure liquidity outflow through taxation, should, in contrast, not matter for these firms, since external and internal capital are perfect substitutes. For financially constrained firms, I expected the opposite. For these firms, the investment decision should depend to a strong degree on internal finance and thus on the EATR and to a smaller extend on the EMTR.

To overcome the critique passed on prior studies, I control for the self-selection of the firms into one of the two financial regimes by employing a switching regression with known sample selection. Based on the firm's cash flow identity, firms are classified as financial constrained on the on hand, if they do not payout dividends and do not issue new shares, and as financially unconstrained if their debt ratio is above the median and no new shares are issued, on the other. To test whether unconstrained firms react more strongly to changes in the EMTR than constrained firms, and whether unconstrained firms react less strong to changes in the EATR than constrained firms, I base the analyzes on the neoclassical investment approach where the EMTR is included in the $U C C$ and the EATR is explicitly included as one important determinant of internal finance.

My results are in line with the theoretical predictions: Firstly, the investment decision of financially unconstrained firms does not depend on the EATR but on the EMTR. The elasticity of capital to its user costs for these firms is around -1 . Secondly, the investment decision of financially constrained firms does depend on the $E A T R$, whereas the elasticity of capital to its user costs, incorporating the $E M T R$, is not statistically different from zero.

In addition, my results show that in case of neglecting the presence of financial constraints, the coefficients in an ADL are biased. The coefficient of the $U C C$ for the unconstrained firms, however, are comparable to prior findings using models which explicitly rely on the long term relationship of $U C C$ and capital stock (Dwenger (2009) and Buettner and Hoenig (2011)). Thus, the findings suggest that the latter models do not suffer from "misspecification" in case some firms face financial constraints. This is in line with the results by Hovakimian and Hovakimian (2009) who showed that financially constrained firms invest less in bad cash flow years and more in good cash flow such that the long term relationship between capital and its $U C C$ is the same for constrained and unconstrained firms.

Further, even though the coefficient for the selection therms due to different financial regimes 
are partially significant, the point estimates of the variables do not change when the selection term is excluded. Thus, although self selection is present, it does not bias - at least for the data set used in this study - the coefficients of interest. 


\section{References}

Almeida, H., and M. Campello (2007) 'Financial constraints, asset tangibility, and corporate investment.' The Review of Financial Studies 20(5), 1429-1460

Arrow, K. J., H. B. Chenery, B. S. Minhas, and R. M. Solow (1961) 'Capital-labor substitution and economic efficiency.' The Review of Economics and Statistics 43(3), 225-250

Audretsch, D. B., and J. A. Elston (2002) 'Does firm size matter? evidence on the impact of liquidity constraints on firm investment behavior in germany.' International Journal of Industrial Organization 20(1), 1-17

Behr, A. (2005) 'Investment, q and liquidity. evidence for germany using firm level panel data.' Jahrbuecher für Nationaloekonomie und Statistik 225(1), 2-21

Behr, A., and E. Bellgardt (2000) 'Investitionsverhalten und liquiditaetsrestringiertheit.' Jahrbuecher für Nationaloekonomie und Statistik 220(3), 257-283

Bond, S., D. Harhoff, and J. van Reenen (2003a) 'Investment, r \& d and financial constraints in britain and germany.' Discussion papaer, Centre for Economic Performance No. 0595

Bond, S., J. A. Elston, J. Mairesse, and B. Mulkay (2003b) 'Financial factors and investment in belgium, france, germany, and the united kingdom: A comparison using company panel data.' The Review of Economics and Statistics 85(1), 153-165

Bond, Stephan, and Costas Meghir (1994a) 'Dynamic investment models and the firm's financial policy.' The Review of Economic Studies 61(2), 197-222

_ (1994b) 'Financial constraints and company investment.' Fiscal Studies 15(2), 1-18

Brainard, W. C., and James Tobin (1968) 'Pitfalls in financial model building.' American Economic Review 58(2), $99-122$

Buettner, T., and A. Hoenig (2011) 'Investment and firm-specific cost of capital: Evidence from firm-level panel data'

Chatelain, J. B. (2003) 'Structural modelling of financial constraints on investment: Where do we stand?' In Firms' investment and finance decision, ed. Butzen P. and Fuss C. pp. 40-58

Chirinko, R., and Ulf von Kalckreuth (2003) 'On the german monetary transmission mechanism: Interest rate and credit channels for investment spending.' Discussion paper, CESifo No. 838 
Chirinko, Rob (1993) 'Business fixed investment spending: Modeling strategies, empirical results, and policy implications.' Journal of Economic Literature 31(4), 1875-1911

Chirinko, Rob, S. M. Fazzari, and A.P. Meyer (1999) 'How responsive is business capital formation to its user cost? an exploration with micro data.' Journal of Public Economics $74(1), 53-80$

Cleary, S., P. Povel, and M. Raith (2007) 'The u-shaped investment curve: Theory and evidence.' Journal of Financial and Quantitative Analysis 42, 1-40

Dwenger, N. (2009) 'Corporate taxation and investment: Explaining investment dynamics with firm-level panel data.' Discussion Papers of DIW Berlin 924, DIW Berlin, German Institute for Economic Research

Eisner, R., and M. Nadiri (1968) 'Investment behavior and neo-classical theory.' The Review of Economics and Statistics 50(3), 369-382

Fazzari, S. M., R. G. Hubbard, and B. C. Petersen (1988) 'Financing constraints and corporate investment.' Brookings Papers on Economic Activity 19(1), 141-195

- (2000) 'Investment-cash flow sensitivities are useful: A comment on kaplan and zingales.' The Quarterly Journal of Economics 115(2), 695-705

Gilchrist, S. (1991) 'An empirical analysis of corporate investment and financing hierarchies using firm level panel data.' Master's thesis, Mimeograph, Board of Governors of the Federal Reserve System

Gilchrist, S., and C. Himmelberg (1995) 'Evidence on the role of cash flow for investment.' Journal of Monetary Economics 36(3), 541-572

Godfrey, L. (1999) 'Instrument relevance in multivariate linear models.' The Review of Economics and Statistics 81, 550-552

Goolsbee, Austin (1998) 'Investment tax incentives, prices, and the supply of capital goods.' The Quarterly Journal of Economics 113(1), 121-148

_ (2000) 'The importance of measurement error in the cost of capital.' National Tax Journal $53,215-228$

- (2004) 'The impact of the corporate income tax: evidence from state organizational form data.' Journal of Public Economics 88(11), 2283-2299 
Guariglia, A. (2007) 'Internal financial constraints, external financial constraints, and investment choice: Evidence from a panel of uk firms.' Journal of Banking \& Finance 32(9), 17951809

Hall, R. E., and D. Jorgenson (1967) 'Tax policy and investment behavior.' American Economic Review 57, 391-414

Harhoff, D., and F. Ramb (2001) 'Investment and taxation in germany /- evidence from firmlevel panel data.' In Investing today for the world of tomorrow /- Studies on the investment process in Europe, ed. Deutsche Bundesbank (Springer, Heidelberg) pp. 47-84

Hayashi, F. (1982) 'Tobin's marginal q and average q: A neoclassical interpretation.' Econometrica 50(1), 213-24

Heckman, J. (1979) 'Sample selection bias as a specification error.' Econometrica 47(1), 153-161

Hovakimian, G. (2009) 'Determinants of investment cash flow sensitivity.' Financial Management $38,161-183$

Hovakimian, G., and A. Hovakimian (2009) 'Cash flow sensitivity of investment.' European Financial Management 15(1), 47-65

Hovakimian, G., and S. Titman (2006) 'Corporate investment with financial constraints: Sensitivity of investment to funds from voluntary asset sales.' Journal of Money, Credit and Banking 38(2), 357-374

Hubbard, R. G. (1998) 'Capital-market imperfections and investment.' Journal of Economic Literature 36(1), 193-225

Hubbard, R. G., A. K. Kashyap, and T. Whited (1995) 'Internal finance and firm investment.' Journal of Money, Credit, and Banking 27(3), 683-701

Jorgenson, D. (1963) 'Capital theory and investment behavior.' American Economic Review $52(2), 305-360$

Kaplan, S. N., and L. Zingales (1997) 'Do investment-cash flow sensitivities provide useful measures of financing constraints.' The Quarterly Journal of Economics 112(1), 169-215

- (2000) 'Investment-cash flow sensitivities are not valid measures of financing constraints.' The Quarterly Journal of Economics 115(2), 707-712 
Keuschnigg, C., and E. Ribi (2009) 'Profit taxation and financial constraints.' Discussion paper, University St. Gallen No. 2009-05

Keynes, J. M. (1936) The general theory on employment, interest and money (London Macmil$\operatorname{lan})$

King, M., and D. Fullerton (1984) The taxation of income from capital (Chicago University Press, Chicago)

Lang, L., E. Ofek, and R. M. Stulz (1996) 'Leverage, investment and firm growth.' Journal of Financial Economics 40(1), 3-29

Maddala, G. S., and F. D. Nelson (1974) 'Maximum likelihood methods for the estimation of models of markets in disequilibrium.' Econometrica pp. 1013-1030

Maddala, G.S. (1986) 'Disequilibrium, self-selection, and switching models.' In 'Handbook of Econometrics' (Amsterdam: Elsevier Science.)

Modigliani, F., and M. H. Miller (1958) 'The costs of capital, corporations finance, and the theory of investment.' The American Economic Review 48(3), 261-297

Myers, S. C. (1984) 'The capital structure puzzle.' Journal of Finance 39, 572-592

Roy, A. D. (1951) 'Some thoughts on the distribution of earnings.' Oxford Economic Papers $3,135-146$

Schiantarelli, F. (1995) 'Financial constraints and investment: A critical review of methodological issues and international evidence.' Oxford Review of Economic Policy 12(2), 70-89

Shea, J. (1997) 'Instrument relevance in multivariate linear models: A simple meas.' The Review of Economics and Statistics 79, 348-352

Tobin, J. (1969) 'A general equilibrium approach to monetary theory.' Journal of Money, Credit and Banking 1(1), 15-29

van Binsbergen, Jules H., John Graham, and Yie Yang (2010) 'The cost of debt.' NBER Working Paper Series No. 16023

von Eije, H., and W. Megginson (2008) 'Dividends and share repurchases in the european union.' Journal of Financial Economics 89(2), 347-374 
von Kalckreuth, Ulf (2001) 'Monetary transmission in germany: New perspectives on financial constraints and investment spending.' European Central Bank Working Paper Series No. 109.

Whited, Toni M. (1992) 'Debt, liquidity constraints, and corporate investment: Evidence from panel data.' Journal of Finance 47(4), 1425-60 


\section{A Appendix A}

Table A.1: Share of financially constrained firms by year

\begin{tabular}{|c|c|c|c|}
\hline \multirow[b]{2}{*}{ Year } & \multirow[b]{2}{*}{$\begin{array}{l}\text { Number of } \\
\text { observations }\end{array}$} & \multicolumn{2}{|c|}{$\begin{array}{c}\text { Share of financially constrained firms } \\
\text { according to... }\end{array}$} \\
\hline & & $\begin{array}{l}\text { dividend payout } \\
\text { behaviour }\end{array}$ & $\begin{array}{l}\text { ratio of } \\
\text { liabilities }\end{array}$ \\
\hline 1991 & 872 & 0.32 & 0.37 \\
\hline 1992 & 1,051 & 0.34 & 0.33 \\
\hline 1993 & 1,067 & 0.37 & 0.30 \\
\hline 1994 & 1,102 & 0.37 & 0.31 \\
\hline 1995 & 1,137 & 0.38 & 0.32 \\
\hline 1996 & 1,158 & 0.40 & 0.33 \\
\hline 1997 & 1,205 & 0.42 & 0.35 \\
\hline 1998 & 1,925 & 0.49 & 0.37 \\
\hline 1999 & 1,829 & 0.43 & 0.34 \\
\hline 2000 & 1,733 & 0.32 & 0.27 \\
\hline 2001 & 1,666 & 0.14 & 0.11 \\
\hline 2002 & 1,586 & 0.10 & 0.06 \\
\hline 2003 & 1,611 & 0.34 & 0.24 \\
\hline 2004 & 1,686 & 0.51 & 0.36 \\
\hline 2005 & 1,781 & 0.53 & 0.37 \\
\hline 2006 & 1,825 & 0.56 & 0.39 \\
\hline 2007 & 1,690 & 0.55 & 0.39 \\
\hline 2008 & 888 & 0.47 & 0.36 \\
\hline Total & 25,812 & 0.40 & 0.31 \\
\hline
\end{tabular}

Notes: A firm is classified as financially constrained according to the dividend payout behavior if it does not payout dividends and also issues/issued no new shares in the present or last period. A firm is classified to be financially constrained according to the debt ratio if the ratio of liabilities to total assets is above the median and the firm issues no new shares in the present or past period.

Source: Hoppenstedt firm database and own calculations. 
Table A.2: Share of financially constrained firms by industry

\begin{tabular}{lccc}
\hline & & $\begin{array}{c}\text { Share of financially constrained firms } \\
\text { according to... }\end{array}$ \\
\cline { 3 - 4 } Year & $\begin{array}{c}\text { Number of } \\
\text { observations }\end{array}$ & $\begin{array}{c}\text { dividend payout } \\
\text { behaviour }\end{array}$ & $\begin{array}{c}\text { ratio of bank } \\
\text { liabilities }\end{array}$ \\
\hline Agriculture, Hunting and Forestry & 102 & 0.52 & 0.40 \\
Fishery & 17 & 0.00 & 0.00 \\
Mining, quarrying & 209 & 0.44 & 0.28 \\
Manufacturing & 8,919 & 0.37 & 0.27 \\
Electricity gas and water supply & 4,026 & 0.29 & 0.29 \\
Construction & 511 & 0.39 & 0.27 \\
Wholesale and retail trade, repair of goods & 2,051 & 0.40 & 0.30 \\
Hotels and restaurants & 150 & 0.47 & 0.23 \\
Transport, storage and communication & 1,806 & 0.61 & 0.31 \\
Financial intermediation & 285 & 0.38 & 0.32 \\
Real estate and renting & 6,196 & 0.39 & 0.38 \\
Public administration and defense & 29 & 0.66 & 0.34 \\
Education & 61 & 0.70 & 0.31 \\
Health and social work & 882 & 0.64 & 0.32 \\
Other community activities & 568 & 0.43 & 0.36 \\
\hline Total & 25,812 & 0.40 & 0.31 \\
\hline
\end{tabular}

Notes: A firm is classified as financially constrained according to the dividend payout behavior if it does not payout dividends and also issues/issued no new shares in the present or last period. A firm is classified to be financially constrained according to the debt ratio if the ratio of liabilities to total assets is above the median and the firm issues no new shares in the present or past period.

Source: Hoppenstedt firm database and own calculations.

Table A.3: Descriptive statistics - whole sample

\begin{tabular}{lrrrrrr}
\hline & MEAN & P25 & P50 & P75 & $\begin{array}{r}\text { Within-firm } \\
\text { stand.deviation (a) }\end{array}$ & $\begin{array}{r}\text { Firm-specific } \\
\text { time variation (b) }\end{array}$ \\
\hline$K_{i, t}$ (in 1,000 Euros) & 300,777 & 14,908 & 51,237 & 178,495 & 466,029 & 0.999 \\
$I_{i, t} / K_{i, t-1}$ & 0.114 & 0.027 & 0.071 & 0.132 & 1.833 & 0.999 \\
$U C C_{i, t}$ & 0.128 & 0.102 & 0.126 & 0.148 & 0.012 & 0.871 \\
$\triangle u c c_{i, t}$ & -0.003 & -0.077 & -0.001 & 0.077 & 0.178 & 0.954 \\
$S_{i, t}$ (in 1,000 Euros) & 567,710 & 29,093 & 80,048 & 264,645 & 665,513 & 0.994 \\
$\triangle s_{i, t}$ & -0.023 & -0.069 & 0.002 & 0.070 & 0.265 & 0.995 \\
$\left(C F_{i, t}-\right.$ etp $\left._{i, t}\right) / K_{i, t-1}$ & 0.327 & 0.066 & 0.129 & 0.237 & 0.734 & 0.999 \\
$E A T R_{i, t}$ & 0.105 & 0.000 & 0.006 & 0.056 & 0.494 & 0.998 \\
\hline
\end{tabular}

Notes: a) Using mean-differenced variables, the within-firm standard deviation measures variation in the time dimension of the panel. (b) Following Chirinko et al. (1999), this measure is computed as 1 minus the $R^{2}$ statistic from a regression of each mean-differenced variable on a set of time dummies. 
Table A.4: Descriptive statistics for financially constrained firms according to dividend payout as splitting criterion

\begin{tabular}{lrrrrrr}
\hline & MEAN & P25 & P50 & P75 & $\begin{array}{r}\text { Within-firm } \\
\text { stand.deviation (a) }\end{array}$ & $\begin{array}{r}\text { Firm-specific } \\
\text { time variation (b) }\end{array}$ \\
\hline$K_{i, t}$ (in 1,000 Euros) & 247,712 & 12,317 & 46,024 & 179,282 & 233,237 & 0.995 \\
$I_{i, t} / K_{i, t-1}$ & 0.068 & 0.020 & 0.065 & 0.125 & 0.765 & 0.996 \\
$U C C_{i, t}$ & 0.125 & 0.100 & 0.123 & 0.147 & 0.014 & 0.916 \\
$\triangle u c c_{i, t}$ & -0.009 & -0.075 & -0.007 & 0.071 & 0.212 & 0.967 \\
$S_{i, t}$ (in 1,000 Euros) & 390,761 & 26,634 & 70,115 & 212,616 & 366,855 & 0.996 \\
$\triangle s_{i, t}$ & -0.035 & -0.072 & -0.003 & 0.062 & 0.252 & 0.993 \\
$\left(C F_{i, t}-\right.$ etp $\left._{i, t}\right) / K_{i, t-1}$ & 0.189 & 0.049 & 0.091 & 0.151 & 0.548 & 0.995 \\
$E A T R_{i, t}$ & 0.066 & 0.000 & 0.000 & 0.012 & 0.358 & 0.995 \\
\hline
\end{tabular}

Notes: a) Using mean-differenced variables, the within-firm standard deviation measures variation in the time dimension of the panel. (b) Following Chirinko et al. (1999), this measure is computed as 1 minus the $R^{2}$ statistic from a regression of each mean-differenced variable on a set of time dummies.

Source: Hoppenstedt firm database and own calculations.

Table A.5: Descriptive statistics for financially unconstrained firms according to dividend payout as splitting criterion

\begin{tabular}{lrrrrrr}
\hline & MEAN & P25 & P50 & P75 & $\begin{array}{r}\text { Within-firm } \\
\text { stand.deviation (a) }\end{array}$ & $\begin{array}{r}\text { Firm-specific } \\
\text { time variation (b) }\end{array}$ \\
\hline$K_{i, t}$ (in 1,000 Euros) & 330,948 & 16,540 & 54,387 & 178,007 & 552,066 & 0.999 \\
$I_{i, t} / K_{i, t-1}$ & 0.140 & 0.031 & 0.074 & 0.136 & 2.238 & 0.998 \\
$U C C_{i, t}$ & 0.129 & 0.104 & 0.128 & 0.149 & 0.012 & 0.870 \\
$\triangle u c c_{i, t}$ & -0.000 & -0.078 & 0.001 & 0.080 & 0.176 & 0.953 \\
$S_{i, t}$ (in 1,000 Euros) & 668,319 & 30,271 & 86,732 & 298,689 & 783,517 & 0.993 \\
$\triangle s_{i, t}$ & -0.016 & -0.068 & 0.005 & 0.075 & 0.279 & 0.994 \\
$\left(C F_{i, t}-e t p_{i, t}\right) / K_{i, t-1}$ & 0.406 & 0.083 & 0.158 & 0.292 & 0.813 & 0.997 \\
$E A T R_{i, t}$ & 0.128 & 0.000 & 0.020 & 0.076 & 0.553 & 0.998 \\
\hline
\end{tabular}

Notes: (a) Using mean-differenced variables, the within-firm standard deviation measures variation in the time dimension of the panel. (b) Following Chirinko et al. (1999), this measure is computed as 1 minus the $R^{2}$ statistic from a regression of each mean-differenced variable on a set of time dummies.

Source: Hoppenstedt firm database and own calculations. 
Table A.6: Descriptive statistics for financially constrained firms according to debt ratio as splitting criterion

\begin{tabular}{lrrrrrr}
\hline & MEAN & P25 & P50 & P75 & $\begin{array}{r}\text { Within-firm } \\
\text { stand.deviation (a) }\end{array}$ & $\begin{array}{r}\text { Firm-specific } \\
\text { time variation (b) }\end{array}$ \\
\hline$K_{i, t}$ (in 1,000 Euros) & 277,889 & 14,537 & 50,893 & 204,953 & 402,526 & 0.996 \\
$I_{i, t} / K_{i, t-1}$ & 0.071 & 0.021 & 0.062 & 0.119 & 0.519 & 0.998 \\
$U C C_{i, t}$ & 0.121 & 0.093 & 0.120 & 0.146 & 0.014 & 0.908 \\
$\triangle u c c_{i, t}$ & -0.008 & -0.090 & -0.008 & 0.086 & 0.221 & 0.968 \\
$S_{i, t}$ (in 1,000 Euros) & 390,669 & 28,049 & 67,376 & 195,398 & 398,249 & 0.992 \\
$\triangle s_{i, t}$ & -0.012 & -0.059 & 0.003 & 0.070 & 0.230 & 0.994 \\
$\left(C F_{i, t}-\right.$ etp $\left._{i, t}\right) / K_{i, t-1}$ & 0.238 & 0.044 & 0.093 & 0.167 & 0.595 & 0.998 \\
$E A T R_{i, t}$ & 0.085 & 0.000 & 0.002 & 0.023 & 0.376 & 0.995 \\
\hline
\end{tabular}

Notes: (a) Using mean-differenced variables, the within-firm standard deviation measures variation in the time dimension of the panel. (b) Following Chirinko et al. (1999), this measure is computed as 1 minus the $R^{2}$ statistic from a regression of each mean-differenced variable on a set of time dummies.

Source: Hoppenstedt firm database and own calculations.

Table A.7: Descriptive statistics for financially unconstrained firms according to debt ratio as splitting criterion

\begin{tabular}{lrrrrrr}
\hline & MEAN & P25 & P50 & P75 & $\begin{array}{r}\text { Within-firm } \\
\text { stand.deviation (a) }\end{array}$ & $\begin{array}{r}\text { Firm-specific } \\
\text { time variation (b) }\end{array}$ \\
\hline$K_{i, t}$ (in 1,000 Euros) & 309,984 & 14,991 & 51,467 & 169,910 & 501,227 & 0.999 \\
$I_{i, t} / K_{i, t-1}$ & 0.131 & 0.030 & 0.075 & 0.136 & 2.156 & 0.999 \\
$U C C_{i, t}$ & 0.130 & 0.106 & 0.128 & 0.149 & 0.012 & 0.870 \\
$\triangle u c c_{i, t}$ & -0.002 & -0.073 & 0.001 & 0.074 & 0.172 & 0.955 \\
$S_{i, t}$ (in 1,000 Euros) & 638,926 & 29,625 & 86,685 & 300,363 & 704,875 & 0.995 \\
$\triangle s_{i, t}$ & -0.027 & -0.074 & 0.001 & 0.070 & 0.284 & 0.994 \\
$\left(C F_{i, t}-e t p_{i, t}\right) / K_{i, t-1}$ & 0.363 & 0.078 & 0.146 & 0.264 & 0.774 & 0.998 \\
$E A T R_{i, t}$ & 0.114 & 0.000 & 0.012 & 0.069 & 0.522 & 0.998 \\
\hline
\end{tabular}

Notes: (a) Using mean-differenced variables, the within-firm standard deviation measures variation in the time dimension of the panel. (b) Following Chirinko et al. (1999), this measure is computed as 1 minus the $R^{2}$ statistic from a regression of each mean-differenced variable on a set of time dummies.

Source: Hoppenstedt firm database and own calculations. 
Table A.8: Tests for the goodness of the instruments - dividend payout as splitting criterion

\begin{tabular}{lccccc}
\hline & All firms & CF:UCF & CF:CF & EATR:UCF & EATR:CF \\
\hline Sargan-test $(p$-value) & 0.282 & 0.841 & 0.048 & 0.821 & 0.048 \\
Shea's Partial $R^{2}: \triangle u c c_{i, t}$ & 0.511 & 0.534 & 0.483 & 0.534 & 0.482 \\
Shea's Partial $R^{2}: \triangle u c c_{i, t-1}$ & 0.394 & 0.415 & 0.368 & 0.415 & 0.367 \\
Shea's Partial $R^{2}: \triangle u c c_{i, t-2}$ & 0.388 & 0.408 & 0.364 & 0.408 & 0.363 \\
Shea's Partial $R^{2}: \triangle u c c_{i, t-3}$ & 0.488 & 0.510 & 0.461 & 0.510 & 0.460 \\
Shea's Partial $R^{2}: \triangle$ sales $_{i, t}$ & 0.681 & 0.684 & 0.675 & 0.684 & 0.671 \\
Shea's Partial $R^{2}: \triangle$ sales $_{i, t-1}$ & 0.652 & 0.647 & 0.663 & 0.646 & 0.663 \\
Shea's Partial $R^{2}:\left(c f_{i, t}-\right.$ etp $\left._{i, t}\right) / K_{i, t-1}$ & 0.352 & 0.370 & 0.268 & & \\
Shea's Partial $R^{2}: c f_{i, t} / K_{i, t-1}$ & & & & 0.288 & 0.215 \\
Shea's Partial $R^{2}: E$ ETTR $R_{i, t} / K_{i, t-1}$ & & & & 0.262 & 0.149 \\
\hline
\end{tabular}

Notes: UCF means unconstrained firms, CF constrained firms.

Source: Hoppenstedt firm database and own calculations.

Table A.9: Tests for the goodness of the instruments - debt ratio as splitting criterion

\begin{tabular}{lccccc}
\hline & All firms & CF:UCF & CF:CF & EATR:UCF & EATR:CF \\
\hline Sargan-test $(p$-value) & 0.282 & 0.800 & 0.044 & 0.500 & 0.056 \\
Shea's Partial $R^{2}: \triangle u c c_{i, t}$ & 0.511 & 0.517 & 0.504 & 0.517 & 0.504 \\
Shea's Partial $R^{2}: \triangle u c c_{i, t-1}$ & 0.394 & 0.398 & 0.389 & 0.398 & 0.389 \\
Shea's Partial $R^{2}: \triangle u c c_{i, t-2}$ & 0.388 & 0.392 & 0.383 & 0.391 & 0.383 \\
Shea's Partial $R^{2}: \triangle u c c_{i, t-3}$ & 0.488 & 0.493 & 0.482 & 0.493 & 0.483 \\
Shea's Partial $R^{2}: \triangle$ sales $_{i, t}$ & 0.681 & 0.690 & 0.647 & 0.690 & 0.647 \\
Shea's Partial $R^{2}: \triangle$ sales $_{i, t-1}$ & 0.652 & 0.663 & 0.610 & 0.663 & 0.611 \\
Shea's Partial $R^{2}:\left(c f_{i, t}-\right.$ etp $\left._{i, t}\right) / K_{i, t-1}$ & 0.352 & 0.336 & 0.342 & & \\
Shea's Partial $R^{2}: c f_{i, t} / K_{i, t-1}$ & & & & 0.284 & 0.316 \\
Shea's Partial $R^{2}: E A T R_{i, t} / K_{i, t-1}$ & & & & 0.318 & 0.385 \\
\hline
\end{tabular}

Notes: UCF means unconstrained firms, CF constrained firms.

Source: Hoppenstedt firm database and own calculations. 


\section{B Appendix B}

This appendix describes the calculation of the variables used in the model and their data source. The construction and the description of the variables follow Dwenger (2009).

\section{Gross Investment $I_{i, t}$}

Gross investment is defined as investment in fixed tangible assets and structures plus reposting, less disposals from fixed tangible assets and structures at book values.

\section{Sales $S_{i, t}$}

Sales are measured by turnover, deflated by an industry-specific output price index, provided by the German Statistical Office.

\section{Cash flow $C F_{i, t}$}

Cash flow is income before taxes plus depreciation. The difference between depreciation for firms who create their profit and loss statement according to the whole expenditure method and firms who apply the cost of sales method is neglected.

\section{Effective average tax rate $E A T R_{i, t-1}$}

The EATR is defined as tax payments $\left(e t p_{i, t}\right)$ scaled by the replacement costs of the beginningof-the-period capital stock .

\section{Capital stock $K_{i, t}$}

Gross investment is scaled by the real replacement costs of equipment and structure. This cost of capital is not available in the data and must thus be estimated from historic cost data. The replacement costs of the capital stock are assumed to equal their historic costs in the first year a firm is observed in the data set, adjusted for previous years' inflation. Thereafter, the replacement costs are updated using the perpetual inventory method:

$$
P_{t}^{I} K_{t}=\left(1-\delta_{i, t}\right) P_{t-1}^{I} K_{t-1} \frac{P_{t}^{I}}{P_{t-1}}+P_{t}^{I} I_{t}
$$

where $t=1987, \ldots, 2008, K_{i, t}=$ capital stock, $I_{i, t}=$ gross investment, $P_{t}^{I}=$ price of investment goods, and $\delta_{i, t}=$ depreciation rate.

I assume a depreciation rate of 12.25 percent per year for fixed tangible assets and 3.61 percent per year for buildings as in Dwenger (2009). 


\section{Price indices $p_{t}^{I}$ and $p_{t}^{S}$}

The price index $p_{t}^{I}$ (Investitionsgueterindex) is constructed at the country level and the price index $p_{t}^{S}$ (Erzeugerpreisindex) on a disaggregated level for manufactures by the German Statistical Office. I use this information at the four digit industry level. Rate of economic depreciation $\delta_{a, j, t}$ The rate of economic depreciation $\delta_{a, j, t}$ can be derived from the national accounts capital stock (Kapitalstockrechnung), provided by the German Statistical Office. The rate is asset (fixed assets and structures), industry (four-digit-level) and time-specific. The rate of economic depreciation is calculated in prices of 2000 .

\section{Depreciation allowances $z_{a, t}$}

In Germany, allowances for fixed assets and structures follow different methods. Structures are depreciated on a straight line basis, whereas fixed assets could also be depreciated according to the declining-balance method until 2007. The rates of depreciation are set by the Federal Ministry of Finance. Due to data restrictions, only regular depreciation allowances are considered. Until 2000, the relevant lifetime of structures for tax purposes was 25 years, since 2001 this lifetime is $331 / 3$ years. Until 2000 the yearly rate for the declining balance method was 0.3 for fixed assets, since 2001 the rate is 0.2 . Because of missing information about the relevant lifetime for different fixed assets, I assumed a relevant lifetime of 10 years until 1997, 13 years between 1998 and 2002 and 16.9 years from 2001 on as in Dwenger (2009) based on the investigation of depreciation allowances in Germany from Oestreicher and Spengel (2002).

\section{Interest rate $r_{t}$}

I used the overall yield on corporate bonds $r_{t}$, provided by the German Central Bank in its series "Yields on debt securities outstanding issued by residents/corporate bonds/monthly average". 
Table B.1: Statutory tax rates over time.

\begin{tabular}{lccc}
\hline Year & $\begin{array}{c}\text { Corporate income tax } \\
\text { on retained earnings }\end{array}$ & $\begin{array}{c}\text { Corporate income tax } \\
\text { on distributed profits }\end{array}$ & $\begin{array}{c}\text { Solidarity } \\
\text { surcharge }\end{array}$ \\
\hline 1987 & $56,0 \%$ & $36,0 \%$ & - \\
1988 & $56,0 \%$ & $36,0 \%$ & - \\
1989 & $56,0 \%$ & $36,0 \%$ & - \\
1990 & $50,0 \%$ & $36,0 \%$ & - \\
1991 & $50,0 \%$ & $36,0 \%$ & $3.75 \%$ \\
1992 & $50,0 \%$ & $36,0 \%$ & $3.75 \%$ \\
1993 & $50,0 \%$ & $36,0 \%$ & - \\
1994 & $45,0 \%$ & $30,0 \%$ & $7.50 \%$ \\
1995 & $45,0 \%$ & $30,0 \%$ & $7.50 \%$ \\
1996 & $45,0 \%$ & $30,0 \%$ & $7.50 \%$ \\
1997 & $45,0 \%$ & $30,0 \%$ & $7.50 \%$ \\
1998 & $45,0 \%$ & $30,0 \%$ & $5.50 \%$ \\
1999 & $45,0 \%$ & $30,0 \%$ & $5.50 \%$ \\
2000 & $45,0 \%$ & $30,0 \%$ & $5.50 \%$ \\
2001 & $25,0 \%$ & $25,0 \%$ & $5.50 \%$ \\
2002 & $25,0 \%$ & $25,0 \%$ & $5.50 \%$ \\
2003 & $26.5 \%$ & $25,0 \%$ & $5.50 \%$ \\
2004 & $25,0 \%$ & $25,0 \%$ & $5.50 \%$ \\
2005 & $25,0 \%$ & $25,0 \%$ & $5.50 \%$ \\
2006 & $25,0 \%$ & $25,0 \%$ & $5.50 \%$ \\
2007 & $25,0 \%$ & $25,0 \%$ & $5.50 \%$ \\
2008 & $15,0 \%$ & $15,0 \%$ & $5.50 \%$ \\
\hline
\end{tabular}

Source: Own representation, corporate income tax law, 1987 to 2008, solidarity surcharge law 1991 to 2008. 